\title{
CriminologicAl AND LEgAL ASPECTS OF USURY CRIME
}

\author{
KRYMINOLOGICZNE I PRAWNE ASPEKTY \\ PRZESTĘPSTWA LICHWY
}

\begin{abstract}
The phenomenon of private loans, in line with the financial seekers seeking financial help, is often criminal activity based on obligatory debtors' positions. The disproportionate benefit imposed on borrowers related to their involuntary position is theoretically their choice, and in practice often the only way to meet basic needs. The research goal of the work is a criminological analysis of the phenomenon of usury, which will certainly allow a deeper understanding of the causes of this prohibited act and the grounds that become arguments for criminal activity. Practical evaluation of the possibility of using art. $304 \mathrm{kk}$ will allow you to answer the question about the effectiveness of this regulation. It is also worth considering the thesis: is there a possibility of amending the provision allowing to increase its function entrusted to it in the Penal Code? Demands of de lege ferenda, this is a reflection on the possibility of sealing the legal system, allowing us to fight the crime of usury more efficiently.

\section{STRESZCZENIE}

Problem z płynnością finansową osób fizycznych, jak i podmiotów zbiorowych powoduje poszukiwanie środków na spłatę swojego zadłużenia na każdy z możliwych sposobów. Rynkowe ograniczenia w zakresie udzielania pożyczek i kredytów narzucone przez głównych graczy sprawiają, że nie wszyscy mogą skorzystać z przejrzystej oferty banków i instytucji kredytowych, uwarunkowanej nie tylko ustawowymi regulacjami, ale również nadzorem nad transparentnością rynku finansowego, sprawowanym przez Komisję Nadzoru Finansowego (KNF).
\end{abstract}


Zjawisko prywatnych pożyczek wpisujących się $\mathrm{w}$ potrzeby poszukujących ratunku finansowego pożyczkobiorców to niejednokrotnie działalność przestępcza, bazująca na przymusowym położeniu dłużników. Niewspółmierne świadczenie nakładane na pożyczkobiorców, związane z ich przymusowym położeniem to teoretycznie swobodny wybór, a w praktyce często jedyna droga do zaspokojenia podstawowych potrzeb.

Celem badawczym pracy jest kryminologiczna analiza zjawiska lichwy, która z pewnością pozwoli na głębsze zrozumienie przyczyn występowania tego czynu zabronionego oraz podstaw, jakie stają się argumentacją dla przestępczego działania. Ocena możliwości wykorzystania art. $304 \mathrm{kk}$ pozwoli odpowiedzieć na pytanie dotyczące skuteczności tej regulacji. Warto również pochylić się nad tezą: czy istnieje możliwość nowelizacji przepisu, która pozwalałaby na lepsze spełnianie przez niego funkcji określonej w Kodeksie karnym?

Badania diagnostyczne zostały przeprowadzone w oparciu o dane statystyczne Policji oraz opublikowane raporty Instytutu Wymiaru Sprawiedliwości. Zasadniczo wykorzystano metodę formalno-dogmatyczną oraz analizę i syntezę.

KEYWORDS: law, crime, Scoring, criminology, usury

SŁOWA KLUCZOWE: scoring, lichwa, krymionologia, człowiek

\section{WPROWADZENIE}

Jednym z nieodłącznych elementów prowadzenia działalności gospodarczej, jak również gospodarstwa domowego jest zaciąganie pożyczek i kredytów. Służą one różnorakim celom, zarówno rozwojowi firmy, spłacie bieżących zobowiązań, jak i pomocy w realizowaniu planów i marzeń. Najczęściej firmy czy osoby fizyczne o takie wsparcie finansowe zwracają się do banków. Zdarza się jednak, że instytucje te $\mathrm{z}$ uwagi na niespełnianie restrykcyjnych wymagań, w zakresie np. osiąganych przychodów czy też realnych możliwości spłacania zaciągniętego zobowiązania, odrzucają wnioski klientów. Staje się tak np. gdy potencjalny pożyczkobiorca posiada już zobowiązanie, nadmiernie obciąża swoje możliwości kredytowe, w przeszłości opóźniał się ze spłatą kredytu czy też pożyczki. Co ważne, w przypadku, gdy w trudnej sytuacji finansowej potencjalny kredytobiorca ubiega się o kilka kredytów - i dostaje decyzje odmowne, to takie zachowanie oceniane jest jako bardziej ryzykowne, więc może obniżyć jego scoring. Scoring to metoda wykorzystu- 
jąca narzędzia statystyczne umożliwiające ocenę wiarygodności danego pożyczkobiorcy oraz przewidzenie prawdopodobieństwa, czy będzie miał on problemy $z$ terminowym oddaniem pożyczonych pieniędzy. Jest to metoda oceny ryzyka kredytowego oraz rodzaj badania analizy zdolności kredytowej. Wszędzie tam, gdzie pojawia się ocena zdolności kredytowej, a co za tym idzie możliwość odmowy udzielenia wsparcia finansowego, pojawia się nisza rynkowa. To ona powoduje, że ludzie znajdujący się w trudnym położeniu życiowym podejmują ryzykowną grę o przetrwanie. Starają się uzyskać jakiekolwiek środki, choćby wiązało się to w koniecznością zwrotu o wiele większych pieniędzy niż te, które uzyskali. Chwilowa wizja odsunięcia od siebie problemów z wierzycielami, czy też zaspokojenia podstawowych potrzeb życiowych, zwiększa prawdopodobieństwo podjęcia transakcji obarczonych ryzykiem.

\section{SCORING, CZYLI NIEUGIĘTE PRAWA RYNKOWE}

Zgodnie z wytycznymi Komisji Nadzoru Finansowego ryzyko kredytowe można zdefiniować jako ryzyko nieoczekiwanego niewykonania zobowiązania przez kontrahenta lub pogorszenia się jego zdolności kredytowej, co zagraża wykonaniu takiego zobowiązania. Ocena scoringowa jest obliczana przez każdy bank inaczej (banki wykorzystują różne algorytmy do jej obliczenia). Pod uwagę brany jest zbiór osobistych danych, które są podawane podczas wypełniania wniosku kredytowego, jak również w bardzo dużej mierze nasza punktacja. Ocena punktowa ( $\mathrm{z}$ ang. score) to starannie opracowana formuła matematyczna, która poprzez porównanie naszych danych osobistych i majątkowych do profilu klientów, którzy otrzymali już kredyt, ocenia naszą wiarygodność finansową. Jeżeli nasz profil zbliżony jest do profilu klientów spłacających swoje kredyty, otrzymujemy wyższą ocenę. Zgodnie z ustawą Prawo bankowe banki mogą wspólnie $\mathrm{z}$ bankowymi izbami gospodarczymi utworzyć instytucje upoważnione do gromadzenia, przetwarzania i udostępniania informacji bankom, instytucjom kredytowym i pożyczkowym. Biuro Informacji Kredytowej S.A. to przedsiębiorstwo posiadające największy w kraju zbiór danych o klientach indywidualnych i przedsiębiorcach, także tych dotyczących pożyczek pozabankowych. Posiada ono w swojej bazie informacje o 140,1 mln rachunków należących do 24 mln klientów indywidualnych oraz informacje o historii kredytowej łącznie $1,1 \mathrm{mln}$ firm i innych 
podmiotów, z których czynne zobowiązania kredytowe ma 760 tys. podmiotów. Banki muszą korzystać ze scoringu, gdyż taki obowiązek nakłada na nie KNF. Inaczej jest w przypadku firm pożyczkowych, które mogą, lecz nie muszą korzystać z tej metody. To od właścicieli i zarządów firm pożyczkowych zależy, jak rygorystyczne parametry utrzymają dla oceny wiarygodności swoich klientów, jest to przede wszystkim kwestia ryzyka, jakie są w stanie ponieść. Niemniej jednak będą oni zobligowani do przedstawienia klientowi wiarygodnej informacji dotyczącej produktu.

Oczywiście ustawodawca w przypadku regulowanego rynku dba o standardy mające na celu poszerzenie ochrony prawnej przysługującej konsumentom, którzy nie posiadając specjalistycznej wiedzy w zakresie rynku kredytowego, podpisują umowy o kredyt konsumencki z bankami i instytucjami kredytowymi dysponującymi w tym zakresie znacznie większą od nich wiedzą i doświadczeniem. Ustawa z dnia 12 maja 2011 r. o kredycie konsumenckim ma na celu znoszenie asymetrii informacji, przez zapewnianie konsumentowi dostępu do przejrzystych i czytelnych danych mających za zadanie pomóc mu w podjęciu świadomej decyzji. Przez umowę o kredyt konsumencki rozumie się umowę o kredyt w wysokości nie większej niż 225550 zł, zaś za kredyt konsumencki uważa się w szczególności umowę pożyczki. Kwestia informacji konsumenckiej jest uregulowana w ustawie na dwóch poziomach. Po pierwsze, art. 7 i 8 ustawy o kredycie konsumenckim zobowiązują kredytodawcę i pośrednika kredytowego, którzy reklamują kredyt konsumencki, do podania w reklamie określonych informacji w sposób, który został w tych przepisach sprecyzowany. Niezależnie od obowiązków informacyjnych odnoszących się do reklamy, art. 13-23 przewidują obowiązek przekazania konsumentowi szczegółowo określonych informacji przed zawarciem umowy o kredyt. Po drugie, zgodnie $\mathrm{z}$ art. 11 ustawy kredytodawca lub pośrednik kredytowy są zobowiązani do udzielania konsumentowi wyjaśnień dotyczących treści przekazanych mu informacji i postanowień umowy. Zarówno obowiązek przekazania informacji, jak i obowiązek udzielenia wyjaśnień mają na celu umożliwienie konsumentowi podjęcie decyzji co do zawarcia umowy o kredyt w oparciu o możliwie najpełniejszą wiedzę co do warunków, na jakich kredyt jest udzielany i konsekwencji jego zaciągnięcia. 
Jednak ryzyko, jakie są w stanie ponieść właściciele i zarząd firm pożyczkowych jako kredytodawcy, to często o wiele za mało, by osoby znajdujące się w trudnej sytuacji życiowej uzyskały kredyt lub pożyczkę. Pojawia się więc swojego rodzaju nisza rynkowa, którą wypełnią prywatne pożyczki lub - trafne w tym przypadku ogólne określenie - szara strefa.

\section{KRYMINOLOGICZNE ASPEKTY PRZESTĘPSTWA GOSPODARCZEGO}

Przestępstwo, przestępczość i przestępstwa to trzy podstawowe płaszczyzny badawcze w kryminologii, ściśle ze sobą powiązane.

Edwin Hardin Sutherland wprowadzał i popularyzował w USA pojęcie tzw. White Collar Crime. Zaprezentowana przez niego definicja miała charakter podmiotowy, wskazując, że przestępstwa gospodarcze popełniane są przez sprawców o wysokim statusie społecznym i zawodowym, którzy wykorzystując swoje uprzywilejowanie (głównie majątkowe), dopuszczają się rozlicznych przestępstw powiązanych z szeroko rozumianymi finansami. Aktualnie White Collar Crime najlepiej określa definicja przedstawiona przez Abergel S. Goldsteina, który omawiając przestępczość białych kołnierzyków, wskazał, że zaliczają się do niej głównie przestępstwa popełnione przez osoby fizyczne lub organizacje, zazwyczaj w związku z ich aktywnością biznesową, występujące najczęściej jako oszustwa bądź fałszerstwa, cechujące się przy tym dużym stopniem komplikacji. Występują one zazwyczaj w sferze finansów i przemysłu, gdzie niebezpieczeństwo wykrycia sprawców jest niewielkie.

Jednym z aktualnych problemów obecnej rzeczywistości gospodarczej jest zjawisko lichwy, zwanej również wyzyskiem, czyli pożyczania pieniędzy na bardzo wysoki procent. Polskie prawo, podobnie jak wiele innych systemów prawnych, zakazuje uprawiania lichwy. Przestępstwo lichwy, polegające na wykorzystaniu przymusowego położenia innej osoby przez zawarcie z nią umowy nakładającej na nią obowiązek świadczenia niewspółmiernego ze świadczeniem wzajemnym, ma z pewnością związek z aktualną sytuacją rynkową, realnymi możliwościami zarobkowymi społeczeństwa, obniżaniem wymagań w procedurze określania ryzyka przez instytucje udzielające kredytów konsumenckich. Kryminogennie oddziałuje również typowa dla systemu rynkowego zmiana sytuacji gospodarczej, okresy recesji i prosperity. 
W okresach recesji ludzie interesu próbują ratować swoje firmy różnymi, także nie do końca zgodnymi z prawem, sposobami. Czynnikiem kryminogennym może być niejasne lub niepełne ustawodawstwo w obrębie kwalifikowania konkretnych zdarzeń. Mnogość przepisów, ich wewnętrzna niespójność, niejasność, kazuistyczne tworzenie zapisów prawnych - wszystko to ułatwia obchodzenie przepisów i czyni je martwymi. Złożoność i zawiłość regulacji karnych utrudnia realne korzystanie $z$ danego rozwiązania, przede wszystkim z uwagi na konieczność udowodnienia sprawcy, iż wypełnione są wszystkie ustawowe znamiona czynu zabronionego, bo tylko wtedy można mu zarzucić popełnienie przestępstwa i skorzystać z penalizacyjnej funkcji Kodeksu karnego. Warto zwrócić uwage, iż poza kryminologicznym aspektem złożoności konkretnych przepisów karnych i prawnych możliwości ich zastosowania istnieje również aspekt socjologiczny, a mianowicie prestiżu prawa, rozumianego w tym przypadku jako poważanie, jakim ludzie darzą prawo. Problemy teoretyczne i badawcze socjologii prawa skupiają się również na skuteczności prawa, jego aspektach, takich jak wiara w legitymizm, sankcje prawne, wspomaganie prawa przez normy pozaprawne, przyczyny nieskuteczności i granice skuteczności praw. Niezaprzeczalnie jednak specyfika przestępstw gospodarczych, do jakich zalicza się lichwa, wymaga posiadania przez sprawcę odpowiednich cech.

Należy jednak wskazać, że przestępczość gospodarcza od początku jej istnienia ewoluuje, jest przy tym zjawiskiem niezmiernie skomplikowanym zarówno pod względem podmiotowym, jak i przedmiotowym. Dlatego też niemożliwe wydaje się podanie jednej, ogólnej (uniwersalnej) definicji przestępczości gospodarczej, która przetrwałaby próbę czasu. Zawsze definicja taka uzależniona będzie również od tego, jak ujmuje się prawo karne gospodarcze w danym systemie prawnym. Można jedynie pokusić się o przedstawienie cech charakterystycznych przestępczości gospodarczej (np. jest to fakt, że sprawcy przestępstw zazwyczaj są uczestnikami obrotu gospodarczego, że naruszają ponadindywidualne interesy gospodarcze, że często wykorzystują zaufanie innych uczestników obrotu itd.) i w ten sposób wyznaczać jej zakres.

Agresywny marketing stosowany przy reklamowaniu pożyczek jako alternatywy dla kredytów bankowych i trafnego rozwiązania dla osób, które nie posiadają zdolności kredytowej np. z powodu niskiego lub nieudokumen- 
towanego dochodu, to nic innego jak umiejętność pozyskiwania zaufania, zaskakiwania profesjonalizmem. Sprawcy aranżują pozory skrupulatnego przestrzegania reguł obrotu. Tworząc pozory niesienia pomocy podmiotom w trudnej sytuacji finansowej, które dzięki kolejnej pożyczce będą mogły spłacić wszystkie zadłużenia i zobowiązania, stosują socjotechniczne tricki w manipulacyjny, oszukańczy sposób, a tym samym wprawiają w ruch narastającą spiralę zadłużenia z jej katastrofalnymi skutkami. Cechy charakteryzujące osobowości sprawców przestępstw gospodarczych to z pewnością wyrafinowanie, przeważnie inteligencja. Sprawca zorientowany jest na bezpośrednie efekty, zaś jego uzdolnienia kombinatorskie górują nad poziomem myślenia abstrakcyjnego. Jego wyobraźnia na ogół funkcjonuje jednokierunkowo. $\mathrm{Z}$ tego też powodu często nie jest on w stanie zrozumieć naganności swego czynu, którego ujawnienie uważa za „pech” lub „zmowę konkurentów”.

Przymus prawny sankcjonujący patologiczne zachowania społecznie tworzą wszystkie legalne, prawnie określone środki zmuszające adresatów prawa do jego przestrzegania. Środki te określa państwo, przez co przymus prawny nabiera charakteru przymusu państwowego.

\section{CZYN ZABRONIONY POLEGAJACY NA WYZYSKANIU PRZYMUSOWEGO POŁOŻENIA INNEJ OSOBY}

Nakaz powstrzymania się od wyzyskania przymusowego położenia innej osoby ustawodawca chce wymóc poprzez penalizowanie lichwy jako zachowania polegającego na nałożeniu na podmiot znajdujący się w trudnej sytuacji obowiązku świadczenia niewspółmiernego ze świadczeniem wzajemnym. Ustawa z dnia 19 kwietnia 1969 r. Kodeks karny zachowanie takie umieściła w art. 207 kk: „Kto, wyzyskując przymusowe położenie innej osoby, zawiera z nią umowę nakładającą na nią obowiązek świadczenia oczywiście niewspółmiernego ze świadczeniem wzajemnym, podlega karze pozbawienia wolności od 6 miesięcy do lat 5”. Co istotne, artykuł ten umieszczony był w rozdziale XXIX kk, zatytułowanym „Przestępstwa przeciwko mieniu”. W tym zakresie ustawodawca wzorował się na Kodeksie karnym z 1932 r., zmianie uległa jednak odpowiedzialność karna za popełnienie przestępstwa lichwy. Mianowicie w Kodeksie karnym z 1969 r. zrezygnowano z kary aresztu, jak również wykreślono z przepisu słowo „majątkowe”, co spowodowało, 
iż określenie „lichwa” zostało rozszerzone na świadczenia każdego rodzaju i aby można było pociągnąć do odpowiedzialności za lichwę, zawierana umowa nie musi dotyczyć obowiązku świadczenia majątkowego przez pokrzywdzonego. Warto jednak zauważyć, że przepis ten po wprowadzeniu nowego kodeksu z 1969 r. i tak miał stosunkowo niewielkie zastosowanie.

W aktualnie obowiązującym Kodeksie karnym z 1997 r. w artykule dotyczącym przestępstwa lichwy przyjęto nowe założenia. Co istotne, artykuł ten został przeniesiony do rozdziału XXXVI zatytułowanego „Przestępstwa przeciwko obrotowi gospodarczemu". Zrezygnowano z zapisu, że lichwa zachodzi jedynie wtedy, gdy nałożone świadczenie jest „oczywiście” niewspółmierne. Lichwa wyrażona $\mathrm{w}$ art. $304 \mathrm{kk}$ stała się zatem przestępstwem gospodarczym. Oznacza to, iż zadaniem tego przepisu jest ochrona obrotu gospodarczego, zwalczanie najbardziej niebezpiecznych dla społeczeństwa patologii gospodarki wolnorynkowej. Jest to interwencjonizm skierowany przeciwko wynaturzeniom przynoszącym szkodę państwu i podmiotom uczestniczącym w działalności gospodarczej. Warto wskazać, iż przestępczość gospodarcza często przybiera formę przestępczości zorganizowanej i zawodowej, które są oceniane jako główne zagrożenia dla stosunków społeczno-gospodarczych. Zmiana umiejscowienia przepisu spowodowała, iż głównym celem jego ochrony są ponadindywidualne interesy gospodarcze, zaś ochrona jednostki stała się ubocznym przedmiotem ochrony. W piśmiennictwie pojawiają się głosy, iż przeniesienie przepisu do działu przestępstw przeciwko obrotowi gospodarczemu uwzględnia dynamikę przestępstw lichwy, które zdominowały właśnie obszar działań gospodarczych, będących konsekwencją decyzji ekonomiczno-prawnych przedsiębiorców. Dla pokazania słuszności tych tez oraz ustosunkowania się do nich w dalszej części tekstu pokazana zostanie statystyka wszczynania i prowadzenia przez Policję postępowań przygotowawczych w sprawach dotyczących odpowiedzialności na podstawie art. $304 \mathrm{kk}$.

Ustawodawca rozszerzył krąg pokrzywdzonych, zgodnie z nowym brzmieniem art. $304 \mathrm{kk}$ może to być osoba fizyczna, prawna albo jednostka organizacyjna niemająca osobowości prawnej. Zmiana w Kodeksie karnym z 1997 r. rozszerza kryminalizację na podmioty zbiorowe. Przeniesienie przepisu o lichwie do rozdziału dotyczącego przestępstw gospodarczych ma i tę konse- 
kwencję, że przynajmniej jeden z podmiotów zawierających umowę musi czynić to profesjonalnie, $w$ ramach prowadzonej działalności gospodarczej. Wydaje się więc jasne, że przepis art. $304 \mathrm{kk}$ nie kryminalizuje obecnie zachowań osób dokonujących obrotu nieprofesjonalnego, a więc prywatnego, realizowanego między osobami fizycznymi.

Analizując zachowania wynikające $\mathrm{z}$ omawianego przepisu, należy podkreślić, iż jest to przestępstwo powszechne i popełnić może je każdy. Jego znamiona może wypełnić zarówno sprawca prowadzący samodzielnie działalność gospodarczą z podmiotem profesjonalnym znajdującym się w przymusowym położeniu, jak i z podmiotem nieprowadzącym działalności gospodarczej lub odwrotnie, tzn. podmiot profesjonalny będący dłużnikiem podmiotu nieprofesjonalnego. Zawarcie umowy lichwiarskiej poza obrotem gospodarczym nie jest kryminalizowane. Przestępstwo z art. $304 \mathrm{kk}$ zostaje popełnione $\mathrm{w}$ chwili zawarcia umowy, o której mowa w tym przepisie, jest to więc przestępstwo formalne. Gospodarczy charakter umowy wynika z jej treści, celu oraz charakteru stron. Przestępstwo lichwy można popełnić wyłącznie umyślnie. Czyn zabroniony popełniony jest umyślnie, jeżeli sprawca ma zamiar jego popełnienia, to jest chce go popełnić albo przewidując możliwość jego popełnienia, na to się godzi. W literaturze podkreśla się, że przestępstwo to można popełnić tylko w postaci zamiaru bezpośredniego. Stanowi o tym znamię „wyzyskanie przymusowego położenia", które należy interpretować jako celową działalność sprawcy, który zmierza do wykorzystania sytuacji, w której znalazł się pokrzywdzony, dla osiągnięcia korzyści majątkowej. Przymusowe położenie jest sytuacją niejednoznaczną i ocenianą za każdym razem. Będąc w szczególnie trudnym położeniu, w krytycznej sytuacji życiowej, pokrzywdzony poszukuje rozwiązania, godząc się na niewspółmierne świadczenie. Okoliczności te sprawiają, że zmuszony jest natychmiast zaciągnąć zobowiązanie, brak środków materialnych powoduje konieczność niezwłocznego zadłużenia się na szczególnie uciążliwych warunkach, mimo że grożą mu z tego tytułu jeszcze większe szkody lub doraźne konsekwencje. W przypadku osoby prawnej będzie to stan całkowitej utraty zdolności płatniczej, niemożność kontynuowania bytu ekonomiczno-prawnego. Może to być również związane z koniecznością szybkiego zbywania aktywów celem znalezienia 
środków obrotowych pozwalających na zaspokojenie bieżących zobowiązań związanych z wypłatami dla pracowników, kupnem surowców itp. Dlatego też często sprzedaż pod taką ekonomiczną i psychologiczną presją powoduje obniżenie wartości zbywanego majątku nawet do 30-50\% jego rynkowej wartości. Za „przymusowe położenie”, o którym mowa w przepisie art. 304 kk, nie może być uznawana każda sytuacja pogarszająca warunki pokrzywdzonego. Musi ono być tak dalece niekorzystne, że grozić będzie pokrzywdzonemu bezpośrednio wielką dolegliwością (np. w wypadku osoby fizycznej - niemożnością zaspokojenia podstawowych potrzeb życiowych własnych i rodziny, utratą mieszkania itp.). Istotą "przymusowego położenia” jest też niezbędność uzyskania świadczenia mającego to położenie poprawić oraz brak możliwości odwrócenia niekorzystnej sytuacji w inny sposób niż zawarcie umowy nakładającej świadczenie niewspółmierne. Lichwa opiera się na dwustronnej umowie, aby więc mogło dojść do popełnienia przestępstwa, konieczne będzie zawarcie ważnej w rozumieniu prawa umowy cywilnej. Sama dysproporcja w pomiędzy świadczeniem sprawy a świadczeniem pokrzywdzonego nie jest wystarczająca dla zaistnienia czynu zabronionego. Konieczne jest bowiem wykazanie przymusowego położenia pokrzywdzonego, a więc trudnej, szczególnie uciążliwej sytuacji życiowej. Nie wydaje się, by przymusowe położenie musiało mieć charakter trwały, z pewnością musi ono istnieć w momencie zawierania umowy. Podobnie jak każde inne zdarzenie, przymusowe położenie jest kategorią ocenną i z pewnością stwarza niemałe pole do interpretacji. Co istotne, przestępstwo to nie jest uzależnione od jakiegokolwiek skutku. Samo zawarcie umowy przez strony w warunkach określonych w przepisie będzie wypełniało ustawowe znamiona czynu zabronionego, bez względu na to, czy niewspółmierne świadczenie zostało już wykonane, czy też nie. Jak słusznie wskazuje Oktawia Górniok, przy ocenie przymusowego położenia „należy brać pod uwagę współczesny standard potrzeb materialnych jednostki, odpowiadający dzisiejszemu pojęciu podstawowych potrzeb” (zob. Górniok, 1994, s. 89). Należy jednak rozszerzyć ten pogląd o klauzulę, iż w odniesieniu do różnych osób i sytuacji należy stosować różne standardy. Problem bowiem dotyczy co prawda obiektywnej sytuacji, lecz określonego indywidualnego podmiotu. Dla oceny wartości świadczeń - świadczenia 
wyzyskiwanego oraz świadczenia wzajemnego - właściwa jest chwila zawarcia umowy. Zgodnie z poglądem Sądu Najwyższego samo stwierdzenie lichwiarskiego charakteru umowy nie wystarcza do pociągnięcia do odpowiedzialności za przestępstwo z art. 304 kk, zaś warunkiem niezbędnym tej odpowiedzialności jest ponadto ustalenie, że osoba pokrzywdzona zawierając $\mathrm{z}$ oskarżonym umowę, znajdowała się w przymusowym położeniu (por. wyrok Sądu Najwyższego z 28 stycznia 2010 r., III KK 260/09). W toku prowadzonych śledztw problem dla organów ścigania może stanowić wykazanie, iż występują wszystkie znamiona lichwy, a przede wszystkim udowodnienie podejrzanemu, a następnie oskarżonemu, że wyzyskał przymusowe położenie pokrzywdzonego. Nietrudno wyobrazić sobie linię obrony, która będzie wskazywała po pierwsze, iż podejrzany nie miał świadomości sytuacji finansowej pożyczkobiorcy, a konkretnie jego przymusowego położenia. Po drugie, iż konstrukcja umowy odnosi się do wielu przepisów i regulaminów, zaś pokrzywdzony kwitował zapoznanie się z nimi oraz świadomie wyrażał wolę zaciągnięcia zobowiązania. Zawile skonstruowane umowy nie będą uwypuklały niewspółmiernego świadczenia, a jak można zakładać, pod woalem szeregu karkołomnych zapisów odwołujących się do górnolotnych cytatów zakładających legalność prowadzenia działalności gospodarczej zawierać się będą ukryte opłaty i prowizje, które tak czy inaczej staną się elementem rażąco wygórowanego zobowiązania.

Tak więc główna linia obrończa może się koncentrować na tym, iż niewyczerpane są w pełni znamiona przestępstwa $\mathrm{z}$ art. 304 kk, które dla zaistnienia czynu zabronionego muszą być spełnione łącznie. Ciekawie wobec tego będzie prezentowało się stanowisko Sadu Najwyższego (sygn. V KK 343/07), który odnosząc się do kasacji obrońcy składającego właśnie taki zarzut, orzekł: „skazany udzielał pokrzywdzonym pożyczek, a następnie żądał zwrotu pieniędzy wraz z odsetkami wynoszącymi od $30 \%$ do $50 \%$ pożyczonej kwoty. Wysokość odsetek żądanych przez skazanego nie przystawała do wynagrodzenia możliwego do osiągnięcia w uczciwym obrocie jakiegokolwiek rodzaju, miała zatem ona zdecydowanie lichwiarski charakter. Tak określone w umowie pożyczki obciążenie pożyczkobiorcy przysparzało skazanemu jako pożyczkodawcy korzyści niedających się uzasadnić żadnymi racjami. Tego rodzaju zastrzeżenia umowne na korzyść skazanego godziły 
w porządek prawny i z tych przyczyn musiały zostać ocenione jako sprzeczne $\mathrm{z}$ zasadami współżycia społecznego, a co za tym idzie, takie zachowanie skazanego wypełniło znamię przestępstwa określonego w art. $304 \mathrm{KK}$, czyli nakładania na drugą stronę umowy świadczenia niewspółmiernego ze świadczeniem wzajemnym".

Analizując znamiona czynu zabronionego, jakim jest przestępstwo lichwy, można dostrzec pewnego rodzaju analogię lichwiarskich umów pożyczek z umowami sprzedaży nieruchomości, w których wartość nieruchomości wskazana w umowie jest rażąco niewspółmierna do rynkowej wartości tej nieruchomości. Przeniesienie prawa własności nieruchomości niewynikające $\mathrm{z}$ długu względem nabywającego to prawo, ale z przymusowego położenia i konieczności zbycia nieruchomości kosztem uzyskania rażąco niskiej ceny, skłania do rozważenia, czy taka czynność nie mogłaby zostać zakwalifikowana jako przestępstwo z art. 304 kk. Analiza takiego zachowania sensu largo pozwala przyjąć, że umowa lichwiarska to nie tylko umowa pożyczki środków finansowych, ale każda czynność, w ramach której pokrzywdzony zmuszony przymusowym położeniem, wyzbywa się majątku po rażąco niskiej cenie celem zaspokojenia podstawowych potrzeb. Czy potencjalny podejrzany może bronić się, przywołując fakt, iż jest to czynność, która pod rygorem nieważności wymaga formy notarialnej? Przecież notariusz to nie tylko wyspecjalizowany prawnik, do którego zwracamy się z zamiarem dokonania określonej czynności prawnej, ale także funkcjonariusz publiczny realizujący obowiązki nałożone na niego przez państwo. Z jednej strony reprezentuje on państwo wobec swoich klientów i ma obowiązek zapewnienia realizacji obowiązków klientów wobec państwa. Z drugiej zaś powinien czuwać nad należytym zabezpieczeniem praw i słusznych interesów stron, jak również innych osób, wobec których czynności te mogą powodować skutki prawne.

Czy takie „okazyjne” nabycie nieruchomości również może zostać potraktowane jako lichwiarskie zachowanie?

Odpowiedź na to pytanie ułatwi nam wyrok, które należy potraktować jako swego rodzaju orzeczenie precedensowe. Sąd Apelacyjny w wyroku z dnia 30 grudnia 2013 r. II AKa 423/13 wskazał konieczność badania w toku procesu karnego okoliczności dotyczących ceny wynikającej z umowy 
sprzedaży nieruchomości w przypadku, gdy cena nieruchomości jest rażąco niewspółmiernie niska w stosunku do rzeczywistej wartości nieruchomości w dniu podpisywania aktu notarialnego. Jak wskazał sąd w uzasadnieniu wyroku, ustalenia dotyczące sytuacji materialnej pokrzywdzonej w dniu podpisania aktu notarialnego umowy sprzedaży, przy uwzględnieniu rażąco niewspółmiernie niskiej ceny nieruchomości ustalonej w tymże akcie, winny skłonić sąd pierwszej instancji do rozważenia tego działania pod kątem przepisu art. $304 \mathrm{kk}$.

Odnosząc się do popularnych pożyczek na przewłaszczenie nieruchomości, należy zastanowić się nad rolą notariuszy w przeciwdziałaniu temu - w znacznej części niezgodnemu z prawem - działaniu. Czy notariusze mają obowiązek i możliwość weryfikowania konstrukcji umowy pod kątem zabezpieczenia praw stron oraz przeciwdziałania pokrzywdzeniu pożyczkobiorcy? Z tą materią mierzył się Sąd Najwyższy w kasacji wniesionej przez obrońcę notariusza w postępowaniu dyscyplinarnym, odnoszącym się do kwestii nieprawidłowości związanych ze sporządzeniem aktów notarialnych obejmujących umowy pożyczki, umowy przewłaszczenia na zabezpieczenie i oświadczenia o poddaniu się egzekucji. Sąd w wyroku z dnia 23 września 2016 r., sygn. akt SDI 45/16, wskazał, iż ukształtowanie umowy przewłaszczenia prowadzące do wystąpienia nadmiernego zabezpieczenia i w efekcie do nadmiernego zaspokojenia wierzyciela, któremu dłużnik nie jest w stanie zapobiec, zaś wierzyciel nie ma określonego w umowie prawnego obowiązku zwrotu nadpłaty, może prowadzić nawet do nieważności umowy - art. 58 $\$ 2$ kc i art. 3531 kc (zob. wyrok Sądu Najwyższego z 12 października 2011 r., II CSK 690/10). Mając na względzie przedstawione racje, wolno stwierdzić: skoro sposób i warunki zaspokajania roszczeń wierzyciela z przewłaszczonej nieruchomości podlegają ocenie w perspektywie art. $58 \$ 2 \mathrm{kc}$, według którego nieważna jest czynność prawna sprzeczna z zasadami współżycia społecznego, to - w przekonaniu Sądu Najwyższego - w celu co najmniej zapobieżenia powstaniu stanu nadzabezpieczenia pożyczki i narażenia stron na ryzyko nierzadko kosztownego i długotrwałego sporu sądowego i w konsekwencji wydania przez sąd orzeczenia o nieważności umowy notariusz sporządzający akt notarialny obejmujący umowę przewłaszczenia na zabezpieczenie obowiązany jest określić wartość przewłaszczonej nieruchomości; wymaga tego 
art. $80 \$ 2$ ustawy Prawo o notariacie. Przytoczyć w tym miejscu wypada przykład działalności sprzed zaledwie kilku lat, kiedy to pożyczki na przewłaszczenie nieruchomości były głównym profilem funkcjonowania spółek takich jak Progres Investment SA, notowanej w przeszłości na giełdzie NewConnect. Dziś spółki tej już nie ma, zaś jej zarząd i osoby z nią związane toczą boje w prokuraturze, broniąc się przed zarzutami stworzenia zorganizowanej grupy przestępczej zajmującej się wyłudzaniem nieruchomości pod pozorem umów o przewłaszczenie.

\section{PrzestęPSTWO LiChWY W STATySTyKaCH, POSTULATY DE LEGE FERENDA}

Zgodnie z danymi publikowanymi przez Policję jako główny organ ścigania, który w ramach swoich ustawowych kompetencji zajmuje się zwalczaniem przestępstwa lichwy, czyn ten nie dotyczy znaczącej liczby prowadzonych postępowań przygotowawczych. Uśredniając dane statystyczne znajdujące się w tabeli 1, można śmiało przyjąć, iż każdego roku wszczętych jest ok. 30 postępowań.

Tabela 1.

Statystyki przestępstw $\mathrm{z}$ art. 304 kk

\begin{tabular}{|c|c|c|}
\hline Rok & $\begin{array}{c}\text { Liczba postępowań } \\
\text { wszczętych }\end{array}$ & $\begin{array}{c}\text { Liczba przestępstw } \\
\text { stwierdzonych }\end{array}$ \\
\hline 2016 & 32 & 40 \\
\hline 2015 & 30 & 158 \\
\hline 2014 & 46 & 170 \\
\hline 2013 & 43 & 15 \\
\hline 2012 & 29 & 13 \\
\hline 2011 & 21 & 57 \\
\hline 2010 & 39 & 6 \\
\hline 2009 & 23 & 10 \\
\hline 2008 & 30 & 15 \\
\hline 2007 & 31 & \\
\hline
\end{tabular}

Źródło: http://www.statystyka.policja.pl/ (dostęp: 7.02.2018). 
Czy zatem możemy twierdzić, iż przestępczość w tym zakresie jest marginalna? Aktualne ujęcie art. 304 kk nakłada na organy ścigania i wymiaru sprawiedliwości obowiązek wnikliwego analizowania zawartych umów, z uwzględnieniem także i tego, że nie każda umowa o zwiększonym ryzyku gospodarczym i przewidująca dla jednej ze stron wyższe korzyści oznacza a priori, iż mamy do czynienia z karalnym wyzyskiem jednej ze stron. Wystarczy przytoczyć statystyki zgromadzone przez Instytut Wymiaru Sprawiedliwości (IWS). Według danych zebranych przez IWS oraz resort sprawiedliwości w latach 2008-2012 było tylko dziewięć prawomocnych skazań z art. 304 kk. Zdecydowana większość zgłoszonych spraw zakończyła się umorzeniem śledztwa lub odmową jego wszczęcia. Ponadto w latach 2008-2010 w przypadku 90 zawiadomień o przestępstwie lichwy odmówiono wszczęcia postępowania.

Konstrukcja przepisu z art. 304 kk nakłada na organy wymiaru sprawiedliwości obowiązek wnikliwego analizowania zawartych między stronami umów. Oczywiste jest przecież, na co wskazuje nawet orzecznictwo, że z faktu braku zdolności kredytowej danej osoby nie wynika jeszcze, iż znajduje się ona w tak trudnej sytuacji życiowej, w tym ekonomicznej, że uzyskanie przez nią pożyczki jest nie tylko potrzebne, ale wręcz niezbędne, i dlatego właśnie - zmuszona takim swym położeniem - skłonna jest zawrzeć krzywdzącą dla siebie umowę. W praktyce oznacza to konieczność powoływania biegłego np. z zakresu ekonomii lub wyceny wartości mienia do przeprowadzania wycen, które są czasochłonne i niestety stają się dla prokuratorów koronnym dowodem skłaniających ich do podjęcia decyzji o kierowaniu do sądu aktów oskarżenia. Należy przy tym zastrzec, że przedmiotem badań takiego biegłego nie są znamiona ustawowe przestępstwa lichwy, lecz ekonomiczna wartość umownych świadczeń, a zatem rozgrywany przed sądem proces karny koncentruje się w większości na podważaniu tych opinii, co przy powodzeniu działań obrony niweczy koronny dowód obarczający oskarżonego. Nie można ponadto zapomnieć o kluczowym fakcie dla zaistnienia przestępstwa lichwy, a mianowicie, iż jedna ze strony umowy musi prowadzić działalność gospodarczą.

Powołana przy Ministrze Sprawiedliwości Komisja Kodyfikacyjna Prawa Karnego w latach 2009-2013 prowadziła prace nad nowelizacją części ogólnej i szczególnej Kodeksu karnego. Projekt ustawy o zmianie ustawy - Kodeks 
karny został przygotowany przez zespół ds. zmian w prawie karnym materialnym Komisji Kodyfikacyjnej Prawa Karnego pod przewodnictwem prof. dr. hab. Andrzeja Zolla. Komisja wskazała, iż przestępstwo lichwy zaprojektowane jako art. $294 \mathrm{f} \mathrm{kk}$ to tradycyjne przestępstwo przeciwko mieniu, a nie przeciwko obrotowi gospodarczemu. Umiejscowienie tego przepisu w Rozdziale XXXVI dotyczącym przestępstw przeciwko obrotowi gospodarczemu uczyniło go w znacznej mierze dysfunkcjonalnym. Stąd propozycja komisji, aby przenieść go do Rozdziału XXXV. Jednocześnie proponowane jest wprowadzenie do niego kilku zmian. Ciekawa argumentacja planowanej zmiany wskazywała, iż „W obecnym brzmieniu zachodzi wątpliwość co do wzajemnej relacji i charakteru wyrażeń „zawiera” (umowę) i „nakładając” (obowiązek), a to z uwagi na „czynnościowy” charakter każdej z nich. Ponadto pierwsza z tych czynności określona jest kazuistycznie. W związku z tym, proponowane jest wprowadzenie syntetycznie ujętej czynności „doprowadzania” (do zawarcia umowy) i wskazanie, że określony obowiązek świadczenia stanowi treść umowy".

„Art. 294f. Kto, wyzyskując przymusowe położenie innej osoby fizycznej, prawnej albo jednostki organizacyjnej nie mającej osobowości prawnej, doprowadza ją do zawarcia umowy zobowiązującej tę osobę do świadczenia rażąco niewspółmiernego do świadczenia wzajemnego, podlega karze pozbawienia wolności od 3 miesięcy do lat 5 ".

Zmiana ta nie znalazła się w nowelizowanym Kodeksie karnym. Z pewnością przeniesienie przepisu do rozdziału „Przestępstwa przeciwko mieniu” spowodowałoby zaliczenie czynu zabronionego lichwy do typowej przestępczości kryminalnej skierowanej przeciwko mieniu, obejmującej również prywatne pożyczki. Byłby to mały krok do skuteczniejszej walki ze zorganizowaną przestępczością wyzyskującą przymusowe położenie pokrzywdzonych.

Należy zwrócić uwagę, iż walka z przestępstwem lichwy może opierać się w początkowym stadium na szerokim wykorzystaniu możliwości wykrywczych pozostających w gestii organów ścigania. Jak to zostało przedstawione, trudności w wykazaniu sprawcy przestępstwa lichwy, iż spełnione są ustawowe znamiona czynu zabronionego powodują, że celowe jest stosowanie pracy pozaprocesowej, do której uprawniona jest Policja i inne organy ścigania. Podmioty trudniące się czerpaniem korzyści majątkowej z lichwy funk- 
cjonują na określonym obszarze. W ujęciu jednostkowym nie zawsze istnieje możliwość zgromadzenia materiału dowodowego pozwalającego skierować wobec podejrzanych akt oskarżenia. Zasadna wydaje się więc każdorazowa analiza odnotowanych na określonych regionach zawiadomień o przestępstwie, ewentualnie prowadzonych postępowań karnych dotyczących czynów o podobnym modus operandi sprawców. Należy szukać elementów łączących pewne zdarzenia, takie jak powiązania i występowanie w procesie lichwy tych samych podmiotów, w szczególności: pośredników, notariuszy, pełnomocników czy też samych pożyczkodawców, zaś w przypadku zaistnienia łączności podmiotowo-przedmiotowej, objęcie tych spraw jednym postępowaniem. Nie można również zapominać o ustawowych obowiązkach organów ścigania wynikających z aktywnego prowadzenia pracy operacyjnej polegających na rozpoznaniu środowisk przestępczych. Szeroko prowadzone czynności, ukierunkowywanie informatorów na przestępstwo lichwy, zbieranie informacji o możliwych powiązaniach przestępczych, jak również rzeczywistych beneficjentach osiągniętych z przestępstwa korzyści majątkowych to bardzo cenne dane, które ułatwią prowadzenie postępowania przygotowawczego.

Problematyka trudności kwalifikacji prawnej, jak i przeprowadzania czynności dowodowych związanych z tematyką niniejszej publikacji została poruszona przez Prokuratora Generalnego w wytycznych z 22 sierpnia 2016 r. w sprawie zasad prowadzenia postępowań przygotowawczych dotyczących przestępstw udzielania pożyczek o charakterze lichwiarskim oraz przestępstw oszustwa skutkujących utratą przez pokrzywdzonych prawa własności nieruchomości. Jak wskazał Prokurator Generalny, co do zasady sprawy związane z przestępstwem lichwy powinny być wszczynane i prowadzone pod kątem zaistnienia przestępstwa oszustwa $\mathrm{z}$ art. $286 \$ 1 \mathrm{kk}$, chyba że $\mathrm{z}$ treści zawiadomienia, pogłębionej ewentualnymi wynikami czynności sprawdzających podejmowanych w trybie art. $307 \mathrm{kpk}$, jednoznacznie i bezsprzecznie wynika, iż zachodzi prawdopodobieństwo popełnienia przestępstwa określonego w art. 304 kk. Błędne lub pochopne przyjęcie wstępnej kwalifikacji prawnej czynu jako występku z art. 304 kk, bez gruntownej analizy lub weryfikacji okoliczności, które mogą świadczyć o zaistnieniu przestępstwa z art. 286 $\$ 1 \mathrm{kk}$, może mieć poważne następstwa, stanowiące rezultat diametralnie różnych zagrożeń karnych przewidzianych przez ustawodawcę dla przestępstw 
z art. $286 \$ 1 \mathrm{kk} \mathrm{i} \mathrm{z} \mathrm{art.} 304 \mathrm{kk}$, co przekłada się na zróżnicowanie okresów przedawnień tych czynów, a w konsekwencji na możliwość ścigania ich sprawców. Oczywiście nie można przy tym zapomnieć, iż przedmiot rodzajowy obydwu wskazanych przepisów jest różny.

Stopień zagrożenia przestępczością gospodarczą, polegający na powiązaniu świata biznesu ze światem przestępczym, jest ciągle niedostatecznie obecny w świadomości społecznej. Cechy, jakimi charakteryzuje się ta przestępczość, a więc najczęściej brak elementu przemocy czy też anonimowość ofiar, bardzo dobrze oddaje sedno lichwiarskich pożyczek. Sprawcy przestępstw dysponują najczęściej profesjonalnym zapleczem prawno-finansowym i wykorzystują niewiedzę oraz trudne położenie pokrzywdzonych dla własnych korzyści majątkowych. Trudna sytuacja materialna pożyczkobiorców, konieczność ratowania swojego bytu, dobrowolne zawiązywanie umów pożyczki celem wyrwania się ze spirali zadłużenia - tak przebiega proces stawania się ofiarą przestępstwa lichwy, ciągle słabo obecny w świadomości społecznej.

\section{Literatura}

Błachut, J., Gaberle, A., Krajewski, K. (2004). Kryminologia, Gdańsk: Wydawnictwo ARCHE. ISBN 8387570060.

Bojarski, M. (2006). Kodeks Karny. Komentarz, wyd. 2, Warszawa: LexisNexis. ISBN 9788373346819.

Buczkowski, K. (1999). Przestęstwo lichwy w kodeksie karnym - przeszłość i teraźniejszość, „Państwo i Prawo” nr 7. ISSN 0031-0980.

Czajka, D. (2000). Przestępstwa menedżerskie, Warszawa: Wydawnictwo Zrzeszenia Prawników Polskich.

Giezek, J. (red.). (2014). Kodeks karny. Część szczególna. Komentarz, Warszawa: Wolters Kluwer Polska. ISBN 9788326441998.

Grześkowiak, A., Wiak, K. (red.). (2018). Kodeks Karny. Komentarz, wyd. 5, Warszawa: Wydawnictwo C.H. Beck. ISBN 9788325596507.

Górniok, O. (1994). Przestępczość gospodarcza i jej zwalczanie, Warszawa: Wydawnictwo Naukowe PWN.

Hołyst, B. (2009). Kryminologia, Warszawa: LexisNexis. ISBN 8301114673.

Kojder, A. (2011). Godność i siła prawa, Warszawa: Oficyna Naukowa. ISBN 8388164317. 
Kozłowska-Kalisz, P., Szczekala, A. (2014). Przestępstwo lichwy (w świetle badań empirycznych), „Prawo w Działaniu” nr 18. ISSN 2084-1906.

Królikowski, M., Zawłocki, R. (red.). (2017). Kodeks karny. Część szczególna. Tom II. Komentarz. Art. 222-316, wyd. 4, Warszawa: Wydawnictwo C.H. Beck.

Krużołek, K. (2013). Prawnofinansowe aspekty zwalczania lichwy bankowej, „Studia Prawnicze. Rozprawy i Materiały" nr 1. ISSN 1689-8052.

Mozgawa, M. (red.). (2017). Kodeks karny. Komentarz, Warszawa: Wolters Kluwer Polska. ISBN 9788381075442.

Osajda, K. (red.). (2017). Kredyt konsumencki. Komentarz, wyd. 1, Warszawa: wyd. C.H. Beck, Legalis/el.

Tokarczyk, R. (2009). Filozofia prawa, Warszawa: LexisNexis. ISBN 9788376202907.

Wytyczne Prokuratora Generalnego z 22.08.2016 r. w sprawie zasad prowadzenia postępowań przygotowawczych o przestępstwa udzielania pożyczek o charakterze lichwiarskim oraz o przestępstwa oszustwa skutkujące utratą przez pokrzywdzonych prawa własności nieruchomości.

Zaleski, T. (red.). (2015). Przestępstwa przeciwko mieniu i gospodarcze, Tom 9, wyd. 2, Warszawa: C.H. Beck. ISBN 9788325529284.

Żółtek, S. (2009). Prawo karne gospodarcze w aspekcie zasady subsydiarności, Warszawa: Gandalf. ISBN 9788376015040.

\section{Akty prawne}

Rozporządzenie Prezydenta Rzeczypospolitej z dnia 11 lipca 1932 r. Kodeks Karny (Dz.U. z 1932 r. nr 60, poz. 571 ze zm.).

Ustawa z dnia 29 sierpnia 1997 r. Prawo Bankowe (Dz.U. z 1997 r. nr 140, poz. 939 ze zm.).

Ustawa z dnia 12 maja 2011 r. o kredycie konsumenckim (Dz.U. z 2011 r. nr 126, poz. 715 ze zm.).

Ustawa z dnia 14 lutego 1991 r. Prawo o notariacie (Dz.U. z 1991 r. nr 22, poz. 91 ze zm.). Ustawa z dnia 23 kwietnia 1964 r. Kodeks cywilny (Dz.U. z 1964 r. nr 16, poz. 93 ze zm.).

Projekt $z$ dnia 5 listopada 2013 r. ustawy o zmianie ustawy - Kodeks karny oraz niektórych innych ustaw - przedstawiony przez Komisję Kodyfikacyjną Prawa Karnego (2009-2013). 


\section{Wyroki}

Wyrok Sądu Najwyższego - Izba Karna z dnia z 28 stycznia 2010 r., sygn. III KK 260/09.

Wyrok Sądu Apelacyjnego w Warszawie - II Wydział Karny z dnia 30 grudnia 2013 r., sygn. II AKa 423/13.

Wyrok Sądu Najwyższego - Izba Karna z dnia 5 marca 2008 r., sygn. V KK 343/07.

Wyrok Sądu Najwyższego - Izba Karna z dnia 28 stycznia 2010 r., sygn. III KK 260/09.

Wyrok Sądu Apelacyjnego w Katowicach - II Wydział Karny z dnia 28 sierpnia 2014 r., sygn. II AKa 240/14.

Wyrok Sądu Najwyższego - Izba Karna z dnia 27 marca 2014 r., sygn. V KK 332/13.

Wyrok Sądu Apelacyjnego w Katowicach - II Wydział Karny z dnia 8 października 2015 r., sygn. II AKa 347/15.

Postanowienie Sądu Najwyższego z dnia 23 września 2016 r., sygn. SDI 45/16.

\section{Źródła internetowe}

https://www.bik.pl/o-nas (dostęp: 6.02.2018).

http://www.statystyka.policja.pl/st/kodeks-karny/przestepstwa-przeciwko17/63940,Lichwa-art-304.html (dostęp: 7.02.2018).

https://www.knf.gov.pl/knf/pl/komponenty/img/BION_PTE_mapa_ryzyka.pdf(dostęp: 10.02.2018).

https://bip.ms.gov.pl/pl/dzialalnosc/komisje-kodyfikacyjne/komisja-kodyfikacyjna-prawa-karnego/komisja-kodyfikacyjna-prawa-karnego-2009-2013/ (dostęp: 7.02.2018).

https://www.pb.pl/wielkie-sprzatanie-po-progresie-858023 (dostęp: 7.02.2018).

http://www.iws.org.pl/analizy-i-raporty/badania-instytutu-wymiaru-sprawiedliwosci-w-ujeciu-tematycznym/ekonomiczne-i-statystyczne-analizy-wymiarusprawiedliwosci (dostęp: 7.02.2018). 